\title{
NARRATION, VETANDE OCH KOMMUNIKATION ICKE-MIMETISKA DRAG I
FÖRSTAPERSONSBERÄTTANDE
}

ÖVERSATT AV MATS FORSSKÅHL

\begin{abstract}
NARRATION, DISCLOSURE AND COMMUNICATION. NON-MIMETIC FEATURES IN FIRST PERSON FICTIONAL NARRATIVE | This article studies the multi-layered nar-
\end{abstract} rative structure distinctive to fiction. The emphasis is on the discoursive and epistemological privileges that are associated with third person narration, but which are also manifested in the first person narratives studied in the article. The article analyzes two historical novels, Suomen historia (1998) by Juha Seppälä, and Kallorumpu (2011) by Eeva-Kaarina Aronen. Both have first person narrators: the largest part of Suomen historia is written like an autobiography, whereas in Kallorumpu the narrator tells about himself, showing and commenting on a film - also featuring himself - to a live audience.

Both novels defy the definition of narrative as communication with symmetrical sender-receiver pairs.

The very act of telling is unclear in terms of temporal and spatial positioning, and so is the amount and order of narrative levels. The narrators and narrative situations are protean, with tenses, deictic markers and other linguistic and contextual cues oscillating between the narrator's and the character's discourse and between narrative audiences. I argue there is a need to revise definitions and terminology to explain non-mimetic, unnatural phenomena in first person fictional narration. I propose the overall concept to be called narratorial functions, and that we divide these into communicative and disclosure functions, the first ones abiding to the rules of communication, the latter defining them.

KEYWORDS I Unnatural narrative, fictionality, first person narrative, disclosure functions; narrative communication, narrative audiences

Ett av de vanligaste sätten att definiera en berättelse de senaste åren har varit James Phelans (I8) formulering som betonar retoriken, och enligt vilken någon berättar för någon annan, $\mathrm{i}$ en viss situation och för ett visst syfte, att något har hänt. Denna definition ser berättelsen som kommunikation, där det finns en avsändare, en mottagare, ett meddelande och en situation. I denna artikel hävdar jag att fiktiv narration inte följer antagandet om vardagligt samtal och berättande som kommunikationssituation, där de nämnda elementen av kommunikation är sinsemellan förenliga. Jag undersöker vilka icke-mimetiska drag som förekommer i 
de behandlade verken och som bryter den narrativa situationen enligt den retoriska definitionen, samt framlägger utifrån dessa min syn på den fiktiva narrationens särart som kommunikativ situation.

Till en början relaterar jag frågeställningen i min artikel och valet av material till den aktuella debatten om en naturlig och en onaturlig narratologi. Denna debatt, som tidvis gått het, handlar just precis om den fiktiva narrationens förhållande till vardaglig kommunikation. Efter detta övergår jag till den textanalytiska delen där jag först granskar exempelverkens narration och dess mimetiska natur som en medveten fråga kring meddelandet och berättaren: vad är det för händelse det berättas om och hur vet berättaren det. Sedan analyserar jag relationen mellan parterna i den narrativa kommunikationen: vad är relationen mellan berättaren och publiken, och vad är deras relation till den narrativa situationen. Utifrån analysen föreslår jag justeringar i de definitioner som gäller den kommunikativa strukturen hos fiktiv, narrativ text.

\section{Fiktionen och berättelsens naturlighet eller onaturlighet}

Inom narratologin har man på senare tid nalkats fiktionens särart via motsatsförhållandet naturlig-onaturlig. Berättelseformens naturlighet och likheterna mellan allt berättande - också fiktionellt - har hävdats tydligast av Monika Fludernik, särskilt i hennes inflytelsefulla verk Towards a 'Natural' Narratology. Enligt Fludernik är prototypen för en narration en muntligt återgiven berättelse, medan textuella eller konstnärliga formuleringar bara utgör variationer av berättande i samtalsform. Hon menar att naturliga faktorer utgör en grund för alla läsare i deras försök att förstå texter. I sitt senaste bidrag till diskussionen försvarar Fludernik ("How Natural" 368) fortsatt sin ståndpunkt och ser i den inriktning som betonar fiktionens onaturlighet en fördel, närmast i det att den lyfter fram den realistiska narrationens fantastiska och omöjliga drag. Hon vill separera det naturliga från det mimetiska och snarare koppla det till att narrationen motsvarar det förväntade och till effektiviteten i kommunikationen: därmed är en naturlig berättelse en framställning som så effektivt som möjligt förmedlar den egna upplevelsen till någon annan. Denna definition har sina primära utgångspunkter i sociolingvistiken och den kognitiva lingvistiken. (Fludernik "How Natural” 358, 360-362.)

Bland de utgångspunkter för en naturlig narratologi som Fudernik ("How Natural” 360-36I) själv räknar upp finns emellertid även Jonathan Cullers begrepp naturalisering. På det bygger Fluderniks centrala tanke om narrativiseringen som en process som omfattar läsarens tolkning och förståelse. Såvitt jag kan se det betonar Fludernik däremot Cullers term på ett annat sätt än han själv gör. Utgångspunkten för Culler (Structuralist Poetics 134 ) är en grundläggande paradox i litteraturen: Det att den avviker från vanlig kommunikation gör den intressant för läsaren. Ändå måste läsaren naturalisera avvikelsen för att förstå litteraturens betydelse och värde. Det här är orsaken till att det finns en grundläggande skillnad mellan Cullers naturalisering och Fluderniks narrativisering. Culler utformade sin 
term för att förklara hur läsare hanterar det märkliga i fiktionen, medan Fludernik ("Natural Narratology" 244-247) uppfattar att läsare utan problem tillämpar samma kognitiva processer och modeller för narrativisering då de tolkar fiktion som de använder i vardaglig kommunikation. Medan Culler med naturalisering avser en operation som förutsätts just precis av fiktionens speciella karaktär, ser Fludernik inte fiktion som något specialfall av tolkning.

Intresset för onaturlig narratologi under de senaste åren kan delvis ses som en återgång till en cullersk förståelse för fiktionens särart. De namnkunniga forskare som utvecklat och stött inriktningen, Jan Alber, Stefan Iversen, Henrik Skov Nielsen och Brian Richardson ("What is Unnatural" 374) betonar i sitt svar på Fluderniks senaste artikel att målet för den onaturliga narratologin är att omforma narratologin så att man i stället för att skapa så omfattande och generaliserbara modeller som möjligt skulle uppmärksamma sådana litterära fenomen som inte följer parametrarna i en tolkningsram som efterliknar verkligheten. Alber et al. ("What is Unnatural" 377-378) lägger fram flera definitioner på hur de var och en uppfattar onaturligheten i narration. Det finns ingen orsak att gå igenom dem i denna artikel. Diskussionen om narrationens naturliga och onaturliga karaktär motiverar ändå valet av material för denna artikel: två historiska romaner som berättas i första person. Berättande i första person har setts som ett prototypiskt fall av naturlig narration i samtalsform. I den historiska romanen är det dessutom en generisk konvention att den fiktiva världen motsvarar det förväntade och till och med är bekant. För historiska romaner som använder jag-berättande finns alltså en tillgänglig mimetisk tolkningsram som följder den vardagliga kommunikationens parametrar såväl för den narrativa formen som för den fiktiva världen. Jag visar emellertid att de behandlade verken bryter den mimetiska kommunikationens ramar.

Exempeltexterna i artikeln tar del i den långvariga diskussionen i Finland om eftervärldens bild av marskalk Carl Gustaf Mannerheim (I867-I95I). Den har behandlats såväl i dockanimationer och romaner som i olika minnesböcker och memoarer. I september 2012 var det premiär för en film där den finsknationella berättelsen har placerats i en afrikansk miljö i Kenya. Eftervärldens bild av Mannerheim granskar också Juha Seppälä på ett kritiskt och parodiskt sätt i verket Suomen historia (nedan SH, på svenska Finlands historia, citaten har översatts för denna artikel) från 1998, och traditionen att revidera bilden fortsätter Eeva-Kaarina Aronen i sitt verk Kallorumpu (nedan KR, på svenska Skalltrumman, citaten har översatts för denna artikel) från 20II. I artikeln granskar jag dessa två romaner, där det i båda två blir oklart hur berättarjagen ska placeras rumsligt, temporalt och diskursivt. Verken ifrågasätter den definition av retoriskt berättande som Phelan (I8) har formulerat, där berättaren och publiken bildar ett symmetriskt avsändar-mottagar-par och den narrativa handlingen imiterar berättande $i$ form av vardagssamtal.

I sin tidigare artikel som definierar onaturlig narration har Alber, Iversen, Nielsen och Richardson ("Unnatural Narratives" II6) delat in narrationens onaturlighet 
i tre former: onaturliga fiktiva världar, onaturliga sinnen och onaturliga narrativa handlingar. I den här artikeln fokuserar jag på den sista av dessa. Enligt Alber et al. ("Unnatural Narratives" I24) kan narrativa handlingar vara onaturliga genom att de fysiskt, logisk, minnestekniskt eller psykologisk är omöjliga. Särskilt i samband med berättande i första person är detta kopplat till ytterligare en onaturlighetsaspekt, nämligen onaturligheten hos ett sinne. Detta framgår även av Alber et al.:s ("Unnatural Narratives” I23-I24) argument: I behandlingen av onaturliga sinnen spelar människosinnets koherens och kontinuitet, så som den framställs i fiktionen, en stor roll, och då handlar det i hög grad om relationen mellan det berättande och berättade jaget. Därigenom handlar både den andra och tredje formen av onaturlig narration om relationen mellan diskurs och berättelse, d.v.s. mellan talare och objekt. Eftersom jag här granskar förstapersonsberättande utgör förhållandet mellan det berättande och upplevande jaget en väsentlig del i undersökningen av de narrativa handlingarna. Därutöver granskar jag historiska romaner, vilket för sin del för in ytterligare ett element i de narrativa handlingarnas natur, och knyter an till den första möjliga källan till onaturlighet på listan, den fiktiva världen.

En tydlig utgångspunkt då det gäller fiktiva romanvärldar erbjuder Dorrit Cohns (The Distinction I3) konstaterande att fiktionen själv skapar världen den hänvisar till just precis genom att hänvisa till den. Detta medför en ömsesidig och simultan relation mellan handlingen att berätta och existensen av det berättade. Detta gäller ändå inte historisk fiktion med referenser till tidigare kända händelser. I sådana fall kompletteras den synkrona relationen mellan berättelse och berättande med en intertextuell länk som läsaren skapar mellan berättelsen och det han eller hon redan vet. Frågan om naturliga och - för fiktionen typiska - onaturliga särdrag i förstapersonsberättande förenas i historiska romaner med frågan om romanvärldens referenser till verkligheten, då den framlagda versionen av det förgångna ställs i relation till läsarens tidigare kunskap, och samtidigt framhävs fiktionens relation inte (endast) till verkligheten utan också till andra texter. Såväl fiktionens inre lager som de yttre, intertextuella lagren framhävs.

\section{Bild och motbild: Om lager i fiktionen}

Den parodiska karaktären hos Seppäläs roman blir klar redan i rubriken, som överdrivet påstår att den korta romanen omspänner Finlands historia. Samtidigt placerar rubriken in Finlands historia som grundtext för romanen. En tydlig referens till nationens historia och konstnärliga framställningar av densamma finns på pärmen i en ekfras som beskriver ett känt finländskt konstverk. På det sättet antyder redan romanens pärm i egenskap av paratext (Genette Paratexts 2, I2) referenser till en konstnärlig tradition snarare än mimetiskt berättande. Referensen mellan olika konstformer placerad före den egentliga berättande texten framhäver en struktur som ger signaler om fiktionens lager. Ett särdrag som särskiljer fiktion från andra former anses vara att författaren och berättaren är separata (se Genette Fiction o Diction 69-78; Cohn The Distinction I23-I3I). Tamar Yacobi ("Interart Narrative” 
7I2-7I7) kopplar denna egenskap till diskussionen om referenser mellan olika konstformer. Enligt Yacobi består fiktionen av inbäddade diskurser där berättare citerar personer o.s.v. Vid intermediala referenser som i en ekfras blir lagren i strukturen tydliga, då det som citeras flyttas från ett medium till ett annat.

I en ekfras beskrivs en målning eller någon annan bildframställning med ord (se Heffernan 299; Mitchell I52; Clüver 26). I Seppäläs roman refererar ekfrasen till Edvard Istos kända politisk-nationella målning "Anfall” (I899). Målningen gjordes under en av förryskningsperioderna, och föreställer Finlands jungfru som strider om en lagbok mot en dubbelhövdad örn som symboliserar Ryssland. Målningen kom att bli en symbol för den finska protesten. I Seppäläs roman beskrivs målningen på följande sätt:

”Den är $200 \mathrm{~cm}$ x I40 cm.

På en klippstrand med ett stormande hav och en dyster himmel i fonden står en stolt ung kvinna med smärtfyllt trots och segerviss kampvilja i blicken. Hon bär en vit dress, på ena axeln en fladdrande, blå duk och ett gyllene bälte med Finlands vapen som spänne. Hennes konturer påminner om Finlands gränser. I sina händer håller hon en stor bok som en tvehövdad örn med spridda vingar attackerar uppifrån. Örnen river i boken med sina vassa klor och håller den krökta näbben över den i en hotfull position. På marken ligger en omkullfallen offerlampa vars låga ännu flämtar svagt. Över horisonten syns ett svagt återsken som förebådar gryning och en klar dag. (SH pärmen).” I

I Sen koko on $200 \mathrm{~cm} \mathrm{x} 140 \mathrm{~cm}$.

Kalliorannalla, taustana

myrskyävä meri ja

synkkäpilvinen taivas, seisoo

uljas nuori nainen katseessa

tuskaista uhmaa ja voiton-

varmaa taistelumieltä. Hän on

valkoisessa puvussa, toisella ol-

kapäällä liehuva,

sininen liina, kultaisessa vyös-

sään koristeena Suomen vaaku-

na. Hänen ääriviivansa muistut-

tavat Suomen rajoja. Kädessään

hän pitää suurta

kirjaa, johon 2-päinen kotka, le-

vitetyin siivin ylhäältä hyökäten

on iskenyt raatelevat terävät

kyntensä, käyrä nokka uhkaa-

vassa asennossa.

Maassa on kaatunut

uhrilamppu, jossa vielä

liekki heikosti lepattaa.

Taivaanrannalla on

kirkasta päivää ennustava

kapea valonkajastus. 
Beskrivningen av tavlan i Seppäläs roman är till synes fylld av patos och patriotism. Författaren har lyft fram de kontraster som finns i målningen, den sårbara men stolta Finlands jungfru och örnen med vassa klor som klöser, samt offerlampan med sin svaga låga och det klara gryningsljuset som förebådar en ny dag. Mot denna bakgrund framställer romanen Mannerheim som jag-berättare, som bl.a. konstaterar: "Jag blev nog en riktig tölp och ett pisshuvud" (SH 32). ${ }^{2}$ Romanen tar sin utgångspunkt i en känd patriotisk målning som skapar associationer hos läsaren till en viss historisk tidpunkt och kanske också mer generellt till Finlands och Rysslands relation som grannar. Mot detta används marskalk Mannerheims påstådda röst på ett sätt som refererar till konfessionella självbiografier. Innehållet som framställs i verket avviker betydligt från läsarens förväntningar: Mannerheim, den nationella hjälten och beskyddaren av Finlands jungfru visar sig i romanen vara en opportunist som inte bryr sig om nationaliteter och en vivör. Läsarens vanliga sinnebild vänds mer eller mindre upp och ned.

Mannerheim används som jagberättare i den mest omfattande delen av romanen. Berättandeformen är intressant på två sätt. För det första begränsas berättar-Mannerheim inte av de epistemologiska gränserna för sin egen tid. I flera sammanhang granskar han händelser sett ur tidpunkten då romanen är skriven. Mannerheim nämner exempelvis att ingen under den beskrivna tiden visste något om nätpornografi (SH 3I). Mannerheim som person hör samtidigt till den grupp som inte visste, eftersom han dog långt innan fenomenet uppstod. Det andra som gör berättandet intressant förekommer genast i inledningen av jag-berättandet. De första satserna Mannerheims berättarröst uttalar är: ”Alla vet vem jag är. Jag är jag." (SH 30.)3 Romanen fäster uppmärksamhet vid det påstådda vetandet och objektet för det. Vem är denna jag som alla vet om?

Uttalandet är intressant till följd av oklarheten i placeringen i tid: Att veta vem Mannerheim är kan referera antingen till Mannerheims samtida eller till de uppfattningar som finns om honom då romanen skrivs. Samtidigt leker inledningsfraserna med läsaren eftersom identiteten hos den "jag" som alla påstås veta om inte har avslöjats. Det handlar inte så mycket om en medveten lucka i berättelsen (jfr. Toker 5-7) som om att förvirra läsarens förväntningar på två sätt: Först vet läsaren inte vem den talare är som påstår sig vara känd. Då läsarens får tillräckligt med textuella vinkar för att kunna identifiera Mannerheim som figur motsvarar inte bilden romanen ger den tidigare kunskapen och de förväntningar denna skapar.

Jagberättaren i romanen Suomen historia använder ett dubbelt perspektiv i relation till de beskrivna händelserna, både i fråga om tid och om vetande. Relationen mellan det berättande och upplevande jaget är flertydig redan i den ovan citerade repliken i början av jagberättandet: "Jag blev nog en riktig tölp och ett pisshuvud" (SH 2). Karakteristiken i lågspråklig stil antyder att talaren är en annan än den omtalade. Men i och med att uttalandet uttrycker vad talaren blev, inte vad han

2 Aikamoinen kollo ja kusipää minusta tuli.

3 Kaikki tietävät kuka minä olen. Minä olen minä. 
var är det svårt att tolka vilket jag, vid vilken tidpunkt talaren fördömer. Detta påverkar tolkningen av om berättaren är en dissonant eller konsonant jagberättare, i konflikt eller samklang med sitt förgångna jag (se Cohn Transparent Minds I43-I72). En dissonant berättare skulle beskriva något om tidpunkten för sin berättelse, varefter han har förbättrat sig, medan en konsonant berättare skulle nöja sig med att konstatera sina karaktärsbrister.

Utdraget avslöjar ett viktigt drag hos Mannerheim-berättaren: frånsett personformen påminner berättandet mer om tredjepersonsberättande, och som sådant snarast ett med extern fokalisering (se Genette Narrative Discourse I89). På flera ställen gissar sig berättaren till sina känslor utifrån dokument, t.ex. då han beskriver sin flytt från Finland till S:t Petersburg: "Kanske jag hade lite dåligt samvete, då jag undertecknade avskedsbrevet till mina släktingar med orden: 'Gustaf, avfällingen”” (SH 35). 4 Ett sådant förhållande till sig själv - såväl ett förgånget som nutida själv - beskrivs lite senare som ett karaktärsdrag: ”Jag är en distanserad människa, framför allt till mig själv" (SH 43.) $)^{5}$ Trots denna delvis naturaliserande ram framstår romanen Suomen historia som en utvikning från jagberättandet. Verket verkar inte bry sig om att skapa en mimetisk berättarram, utan använder fritt en slags omöjlig berättarposition där första person sammanfaller med en yttre granskning av berättarpersonen och ett tidsperspektiv efter personens död.

Man kunde tillämpa Nielsens ("The Impersonal Voice" I39-I40) tanke om en opersonlig röst i berättelsen på Seppäläs roman. Nielsen använder begreppet för att förklara ställen där en jagberättares vetande överskrids genom att jämställa dem med onaturliga egenskaper hos en tredjepersonsberättare. Nielsens poäng om likheterna mellan homo- och heterodiegetiskt berättande och också om jagberättares friheter är träffsäker. Jag stöder ändå inte hans tanke om en separat röst som står över jagberättarna som finner sig i den fiktiva världen. Snarare uppfattar jag då att en homodiegetisk berättare i sin berättargärning kan överskida de naturliga gränserna för vetande och berättande. Det är all anledning att särskilja mellan kategorierna röst och vetande. En röst i en text hör fortfarande till en person, men den implicita författaren laddar personens replik med betydelser som inte har någon grund i den mimetiska berättelsesituationen, utan riktar sig till en publik på en högre nivå. Det här är en del av flexibiliteten i de narrativa nivåerna, med det förutsätter inte antaganden om någon opersonlig röst eller annan tilläggsagent i den narrativa kommunikationen. Samma slutsats har också Nielsen ("Natural Authors") själv kommit till i en nyare artikel. Det är klart att Nielsens poäng om likheterna mellan förstapersons- och tredjepersonsberättande, och särskilt om ett närmande mellan en granskning av förstapersonsberättande och tredjepersonsberättande är viktig. Den hjälper en att förstå berättare som den i romanen Suomen historia, på vilka man tydligen inte kan tillämpa skillnader i homodiegetiskt berät-

4 Kai minulla oli vähän huono omatunto, kun allekirjoitin sukulaisille jättämäni jäähyväiskirjeen sanoin: 'Gustaf, luopio'.

5 Olen etäinen ihminen, ennen muuta itselleni. 
tande, t.ex. konsonans och dissonans mellan ett berättande och förgånget jag. Jag anser dock att det i tolkningen är fruktbarare att granska den berättande röstens inre motstridigheter, och inte att på medvetna grunder förutsätta en redundant berättare som placerar sig ovanför berättarjaget.

\section{Vilken publik? Om språk utan fast position}

Jag konstaterar ovan att romanen Suomen historia betonar sin fiktionalitet genom de referenser mellan konstformer som finns på pärmen. Ekfrasen som beskriver färger, former och föremål sträcker sig intermedialt mot tavlan, sitt objekt, och betonar samtidigt särdragen i visuell och verbal framställning. Det intermediala är ännu tydligare i Aronens verk Kallorumpu. Jagberättaren som tidvis har bott $\mathrm{i}$ Mannerheims hushåll på I930-talet visar i romanvärlden vid tiden för berättandet en egenhändigt gjord film om en dag hemma hos Mannerheim. Berättandet lånar ibland berättarens tal till dem som ser på filmen, och rör sig ibland i berättarens minnen, hans funderingar om att skapa en film och hans redogörelser för den filmförevisning som precis pågår. I berättelsen finns också andra inbäddade berättare, inspelade intervjuer med personer som ingått i Mannerheims hushåll.

Romantexten börjar som en situation i början av filmförevisningen:

”Det här är morgon, här börjar dagen. Först visar jag entrén till Kalliolinnavägen I4. Allt som någonsin har darrat och fladdrat i vinden har här stelnat och blivit tecken.

Min film börjar lite för sent. Fröken Beata Haglind med sin dammvippa håller redan på att försvinna och döljs bakom jägarregementets flagga.” (KR 7.)6

Det demonstrativa pronomenet "det här" i början av romanen innebär en tolkningsutmaning: utpekar det boken, romanens värld eller den film som visas i romanvärlden? Utan en redan skapad fiktiv värld blir läsaren tvungen att fundera på pronomenets referent och betydelse. Också det andra stycket innehåller en liknande oklarhet i hänvisningarna. Då berättaren säger att "min film börjar lite för sent" antar läsaren att han menar att filmförevisningen inleds för sent i romanens fiktiva verklighet. Sedan blir det klart att filmningen har inletts för sent: i den värld som filmen i romanen visar har en person redan hunnit gå sin väg då kameran börjar spela in.

Det fiktionella språkets särskilda sätt att lösgöra sig från temporaliteten i tidsformer har granskats framför allt i samband med tredjepersonsberättande (se Hamburger 39-42; Cohn The Distinction 23-26). I dessa studier har man koncentrerat sig i synnerhet på hur dåtidsformer kan hänvisa till såväl dåtid som nutid och framtid.

6 Tämä on aamua, tästä alkaa päivä. Näytän ensimmäiseksi Kalliolinnantie I4:n eteisaulan. Kaikki, mikä joskus on värähdellyt ja läikehtinyt tuulessa, on täl̈llä puutunut merkeiksi.

Elokuvani alkaa hiukan myöhässä. Neiti Beata Haglind on jo häviämässä pölyhuiskineen näkymättömiin jääkärirykmentin lipun taakse. 
Romanen Kallorumpu visar hur förstapersonsberättande kan använda nutidsform så att dess temporala fästpunkt är oklar och lösgjord från talarens egen tid och rum. Det berättande jaget är på en biograf och visar filmen ("först visar jag...”), men i följande stycke övergår presens till att betyda de förgångna händelserna som visas $i$ filmen, där en hushållerska städar. På samma sätt övergår den rumsliga placeringen från berättanderummet till det beskrivna rummet, då ordet "här" i tredje meningen refererar till ett annat rum, Mannerheims bostad på Kalliolinnavägen.

Om man försöker närma sig verket Kallorumpu med hjälp av teorier som betonar inriktningen på den fiktiva världen och t.o.m. immersion, är det svårt att hitta specifika VAD-, VAR- och NÄR-koordinater för såväl publiken som berättaren (se Herman Story Logic; Basic Elements 8o-82; jfr. Ryan). Berättaren presenterar sin egen roll lite senare i romanen:

”Jag har många uppgifter: jag har varit manusförfattare, scenograf, regissör, fotograf och filmklippare. Nu är jag berättare och projektorskötare. Det som åskådaren sannolikt inte kommer att förstå får jag förklara. En del saker lämnar jag osagda, eftersom jag inte heller själv är säker på dem. Ibland talar jag inte alls, eftersom det som har fångats på film och fotografier räcker som sådana.” (KR 8.)7

Berättaren säger sig "nu” vara berättare och projektorskötare. Det här är den position i romanvärlden som han framlägger för sig själv. Vissa delar av narrationen placerar sig i denna position och riktar sig till publiken i biosalongen. Det citerade utdraget avviker på två sätt från detta. Först och främst är orden delvis berättande som är simultant med handlingarna; berättande, där handling och berättelsen om handlingen verkar sammanfalla ("nu är jag"). Att på detta sätt samtidigt leva och berätta om levandet har ansetts omöjligt enligt narrationens naturliga parametrar (se Cohn The Distinction 96). För det andra riktar sig replikerna i citatet inte till den närvarande publiken, utan berättaren talar till en annan publik, för vilken han berättar om sin situation. Kunskapsmässigt motsvarar detta i någon mån det fenomen Phelan (I2) har kallar redundant berättande (redundant telling).

Som narrativ handling motsvarar ändå exemplet ur romanen Kallorumpu inte redundant berättande eftersom det är tal som öppet riktas till en annan publik som inte är närvarande. Berättaren i Kallorumpu riktar sig ofta tydligt till romanens publik, inte till den publik som befinner sig i samma tid och rum som han, så som i följande utdrag: ”Nu frågar damen i bisamhatt något - ja, varför just den här dagen, den I3 november I935. Jag kunde påstå att den har valts av en slump, att vilken som helst dag innan kriget bröt ut hade gått. Men så är det inte.” (KR

7 Minulla on monta tehtävää: olen ollut käsikirjoittaja, lavastaja, ohjaaja, kuvaaja ja leikkaaja. Nyt olen selostaja ja elokuvakoneenkäyttäjä. Sen, mitä katsoja ei todennäköisesti ymmärrä, joudun selittämään. Jotkut asiat jätän sanomatta, koska en ole itsekään niistä varma. Toisinaan en puhu mitään, koska se, mikä filmille ja valokuviin on vangittu, riittää. 
I59.) $)^{8}$ Här relaterar berättaren händelser under filmförevisningen för romantextens publik. Det är inte fråga om redundant berättande, där det i den mimetiska berättelsesituationen fogas in sådan information, som är avsedd för en publik på högre narrativ nivå. I stället är det fråga om direkt tal riktat till publiken på högre nivå. Därmed passar Nielsens tanke om en berättande röst på en högre nivå inte in här, och inte heller Phelans definition av redundant berättande. Jag hävdar att det finns ett berättarjag, även om det finns flera publiker som tilltalas.

I följande utdrag ser man tydligt hur olika publiker blandas:

”Jag stoppar och lämnar bara ett knastrande mörker på duken och ställer mig framför den.

Man borde tända en tändsticka. Endast för det ögonblick stickan flammar upp kan vi se den smala, långa stigen som löper genom skogen. Visst, det är stjärnklart, som den unga mannen i palestinasjal kräver. Det är en gnistrande stjärnhimmel men under den vajar träden i mörkret, ser ni, de är fulla med små glimmande lampkedjor, men också med små blinkande ögon som dyker upp och försvinner igen bland grenarna. Träden rör sig i den oroliga vinden, nu svajar jag själv för er, av mina armar gör jag grenar som svänger för er på den vita duken, jag drar fram min lilla ficklampa och blinkar med den så att ni ska förstå oron i mörkret. Jag dansar vägen för er.” (KR IO2.) $)^{9}$

Den första meningen är riktad till en heterodiegetisk publik för vilken berättaren relaterar sina handlingar i samband med filmvisningssituationen. Följande mening närmar sig något som liknar en inre monolog, där berättaren funderar över vad han borde göra. I därpå följande mening innefattar pronomenet "vi” berättaren och hans fysiska homodiegetiska publik, som han tänker sig delar någon slags vision med honom. Tilltalet "ser ni" kan vara antingen inre monolog eller tal som riktas till filmpubliken - och man kunde också tänka sig att berättaren bjuder in publiken på högre nivå att föreställa sig den vision han beskriver. De två sista meningarna är tolkningsmässigt rörliga och kan antingen utgöra en rapporterande redogörelse samtidig med själva skeendet för en högre nivås publik, eller tal riktat till den närvarande publiken. Det senare alternativet är möjligt eftersom betydelsen av berättarens handlingar behöver klargöras också för den publik som följer dem; betydelsen av ficklampan och armarna är inte klar.

8 Nyt rouva piisamilakissa kysyy jotakin - niin, miksi juuri tämä päivä, marraskuun I3. vuonna 1935. Voisin väittää, että se on sattumalta valittu, että mikä tahansa päivä ennen sodan syttymistä olisi käynyt. Mutta niinhän se ei ole.

9 Pysäytän valkokankaalle pelkän rätisevän pimeän ja asetun sen eteen. Olisi raapaistava tulitikku. Vain sen hetken, kun tikku leimuaa, näemme metsää halkovan kapean, pitkän polun. On, on tähtitaivas, niin kuin nuorimies palestiinalaishuivissa vaatii. On säkenöivä tähtitaivas, mutta puut huojuvat sen alla pimeässä, näettekö, ne ovat täynnä pieniä loistavia lamppuketjuja, mutta myös välähteleviä silmiä, jotka ilmestyvät ja katoavat oksien lomassa. Puut liikkuvat levottomassa tuulessa, minä huojutan nyt itseäni teille, teen käsivarsistani häilyvät oksat valkokankaalle, tempaisen pienen taskulamppuni ja välkyttelen sitä, jotta ymmärtäisitte pimeän rauhattomuuden. Minä tanssin teille sen tien. 
I Aronens roman används fiktionens möjlighet att lösgöra det framställande språket från en normal förankring i en stabil berättande varelse och position mycket medvetet och mångsidigt. Avsnittet som beskriver berättarens uppgifter innehåller också sammanfattningar ("ibland") och övergångar i tid från förgången till nutid och framtid ("jag har varit", "får jag förklara”, "lämnar jag osagda”; se Genette Narrative Discourse II6, 35-47). På det sättet använder berättaren sådana övergångar i tid och rum som är möjliga för en tredjepersonsberättare (jfr. Nelles; Culler "Omniscience”). Romanen Kallorumpu innehåller flera olika berättandesätt som måste betraktas som onaturliga, än vad man vanligen finner bland förstapersonsberättelser. Nielsen ("The Impersonal" I37-I38) har delat in dem i två klasser, kunskap som skulle vara otillgänglig för en vanlig människa (inklusive detaljrikedom som övergår minnets gränser, och dialog återgiven ordagrann i efterhand) och situationer där berättaren förmedlar vetande som redan är känt för mottagare i den fiktiva världen. Den föregående är ett slags epistemologisk metaleps som Cohn (Transparent Minds I62) har kallat ungefär minnestekniskt överflöd (mnemonic overkill); den senare är det Phelan (I2) kallar redundant berättande. I bägge fall är det fråga om "överflöd”: i det föregående i fråga om berättarens kunskapskapacitet, i det senare av upprepat innehåll i berättandet. Berättaren i Kallorumpu har dessa egenskaper som kallas onaturliga (sin minnestekniska överlägsenhet kommenterar han dessutom själv, KR 205), men ett ännu intressantare drag är växlingen mellan och sammanblandningen av tilltal till en metaleptisk högre nivås publik med ett tilltal till publiken i kommunikationssituationen, så som i det senaste utdraget ovan. Berättaren i såväl Kallorumpu som Suomen historia avviker från en vanlig människas subjektsposition, och romanerna utnyttjar fiktionens möjlighet att lösgöra det framställande språket från en normal förankring i en stabil berättande varelse och position - trots att berättarna formellt är homodiegetiska (jfr. Fludernik ”Towards” 269-3IO). Till de onaturliga egenskaperna hos förstapersonsberättande måste man alltså, utöver de två som Nielsen nämner, foga att nivåerna avsändare-mottagare formellt bryts sönder i tilltalet.

Av skillnaderna mellan naturlig och onaturlig narratologi har en att göra med förståelsen av läsarens roll. Maria Mäkelä (I39-I4I) har skissat upp skillnaden mellan en klassisk och en postklassisk narratologisk läsarbild. Medan den klassiska narratologins läsare är en fingerad kompetent läsare som söker efter textens djupaste specifika betydelse, skapar den postklassiska narratologin å sin sida en bild av en mer jordnära läsare som strävar efter en bekant, koherent och följdriktig tolkning. Särskilt den naturliga, men delvis också den onaturliga narratologin förstår läsaren på ett postklassiskt sätt. Den onaturliga inriktningen betonar ändå i högre grad också textens egenskaper och eventuella fiktionella särdrag. Verk som liksom romanerna Suomen historia och Kallorumpu blandar berättelsenivåer och röster utsätter sina läsare för tolkningsmässiga utmaningar.

Fludernik ("History and Metafiction" 93) har träffande konstaterat att det självreflexiva metafiktiva elementet i postmoderna historiska romaner inte innebär avvikelser från ett historiskt skrivande, utan snarare en anpassning till ny 
begreppsbildning i fråga om både romanen och historieskrivningen. Det är viktigt att notera att varken det att förneka det förgångna eller vända det upp och ner, som bägge de analyserade romanerna gör, innebär ett avståndstagande från framställningen av det förgångna. De referenser till den historiska bakgrunden som förekommer i verken ger läsaren en bekant kunskapsgrund mot vilken den nya texten och dess innehåll kan jämföras. Brian McHale (IOO-IO2) har diskuterat narrativ självutradering (self-erasure), där berättelsen förnekar händelser som tidigare har relaterats. Enligt $\mathrm{McHale}$ kan ett förnekande av sådant som berättats tidigare leda till en radikal ontologisk osäkerhet om den framställda världen. Detta är ändå inte nödvändigt och sker inte alltid. Jag hävdar att en intertextuell länk till tidigare texter om samma händelser är ett drag som balanserar och stabiliserar världen i historisk fiktion. Då de tidigare framställningarna erbjuder en tolkningsram kan det få läsaren att ändra sin uppfattning om de presenterade händelserna, men det är åtminstone inte enkelt att få läsaren att betvivla deras existens.

Linda Hutcheon (I23) konstaterar att postmodern fiktion egentligen inte strävar efter att berätta sanningen utan snarare granska och ifrågasätta vems sanning det är som berättas. I den processen är läsarens roll central och den stöds av olika hänvisningar till intertexter och historieskrivningsprocesser. Den narrativa kommunikationen är inte ett nollsummespel mellan det mimetiska och syntetiska åtminstone inte då det gäller historisk fiktion. Då narrationen betonar sättet att berätta vid sidan av berättelseinnehållet lockas läsaren att inta en tolkningsposition på en högre diegetisk nivå, och jämföra den historiska framställningen intertextuellt och kontextuellt med sin egen förståelse av det förgångna. Man bör alltså notera att varken Kallorumpu eller Suomen historia vänder uppmärksamheten bort från den presenterade fiktiva världen, trots de drag av onaturlig narration som jag har visat på. Det faktum att sättet att berätta ställs i förgrunden liksom att det förekommer avvikelser från den mimetiskt berättande ramen vilka kräver tolkning ger alltså inte upphov till tvivel på att berättelsen existerar eller att den är fantastisk, utan snarare tvivel på möjligheterna att framföra den, på vad dessa berättelser kommunicerar.

\section{Till slut: om berättande och kommunikation}

Phelans (I8) kända retoriska definition av berättelse som någon som berättar något för någon i någon situation och med vissa syften om något som händer förutsätter en mimetiskt trovärdig narrativ situation med avsändare och mottagare. Mitt exempelmaterial visar att subjekt, situationer, betydelser och mottagare inte alls alltid möts på en gemensam diegetisk nivå. Phelans (I2) modell beaktar också detta och han föreslår att man särskiljer berättarfunktioner (narrator functions) och avslöjande funktioner (disclosure functions). Den förra begränsas av de mimetiska gränserna för den narrativa situationen, den senare överskrider dem genom det överflöd av information som ges. Motsvarande åtskillnad föreslår Yacobi ("Fictional Reliability" I23-I26) som delar in innehållet i det sagda i retoriskt och fiktivt innehåll (rhetorical and fictive content). Den senare följer romanvärldens kommunikativa 
situation, den förra bryter mot den. Yacobi menar att ett retoriskt tal avviker från den kommunikativa symmetrin då talaren riktar sig till publiken inom berättelsen men dessutom till romanläsaren.

Yacobis och Phelans distinktioner är användbara, men jag föreslår några preciseringar i terminologin. Nyare diskussion om begreppen fiktiv, fiktionell och retorisk gör Yacobis uppdelning svårtydd. Det Yacobi klassar som fiktivt vill jag hellre kalla mimetiskt, i och med att definitionen av termen har specificerats så att den beskriver det att följa den givna kommunikationssituationen. Med Phelans termer finns två potentiella problem. För det första kan åtskillnaden mellan berättarfunktionen och den avslöjande funktionen leda till att man blandar ihop detta med skillnaden mellan berättarens och en karaktärs funktion, vilken fungerar på en alldeles annan nivå. För det andra - och detta är viktigare här - hänvisar åtskillnaden till en smal förståelse av berättelse och berättare, och sätter ett likhetstecken mellan berättare och talare (narrator and teller).

Mitt förslag är att skillnad görs mellan kommunikativa och informerande funktioner. Jag föreslår en allmän term berättarfunktioner (narratorial functions) som kan delas upp i två: kommunikativa och informerande (communicative and disclosure). De förra följer begränsningarna för en kommunikativ situation, de senare inte. Detta kan också kopplas samman med naturlig och onaturlig narratologisk teori eftersom de kommunikativa kan kallas naturliga och de informerande kan kallas onaturliga berättarfunktioner. Min argumentation ligger nära Nielsens ("Natural Authors" 279) påstående enligt vilket: "one does not have to consider all forms of narration as report and communication". Nielsen menar att en onaturlig berättelse definieras av sådana berättande handlingar som inte är kommunikation. Detta verkar förnuftigt och kompletterar tanken om möjligheten för fiktionens språk att lösgöra sig från och fördunkla talaren deiktiskt. Det jag inte håller med Nielsen ("Natural Authors" 299) om är bara det att han vill betona författarens roll vid tolkningen av ett verk, jag betonar snarare läsaren. Vidare finns det skäl att påpeka att ett överskridande av den kommunikativa situationen inte begränsar sig till informationsinnehållet, vilket såväl Phelan (2005) som Nielsen (20IO) har fäst uppmärksamhet vid. Min analys visar att inte bara innehållet utan också tilltalet, själva den narrativa handlingen, kan rikta sig utanför den narrativa situationen som framställs i den fiktiva världen. Då det gäller fiktiv narration är det viktigt att beakta eventuella asymmetriska relationer mellan paren av avsändare och mottagare, och att beakta hur dessa syns i berättarens sätt att rikta sitt tilltal till publiken eller publikerna.

Culler ("Omniscience" 23-24) har sagt att vetandet är relativt och till och med irrelevant i fiktionen. Som jag ser det är möjligheten att kunna peka ut vetandets subjekt och ursprung en del av fiktionens lek, där man omväxlande avslöjar och fördunklar. Den fiktionella diskursen kan kopplas till en dramatiserad berättarfigur, men dess ursprung ligger alltid hos den implicita författaren, som ändå inte har en egen röst. Jagberättare presenterar sitt livs romanvärld, men alla berättarröster skapar sen fiktiva verkligheten. Rösternas position i någon viss subjektsposition 
eller inriktning mot en särskild publik kan i fiktionen kullkastas på flera sätt, vilket romanerna Suomen historia och Kallorumpu visar. I den första är berättaren formellt sett en person i berättelsen, men talar från ett senare tids- och kunskapsperspektiv till publiken i skrivögonblicket. I den andra rör sig berättaren och svajar mellan olika tider, platser och publiker. I bägge verken påminns läsaren om sin roll både som tolkare av ordkonst och som bedömare av olika versioner av verkligheten genom det märkliga i fiktion som kräver naturalisering.

\section{LITTERATURLISTA}

Alber, Jan, Stefan Iversen, Henrik Skov Nielsen och Brian Richardson. "Unnatural Narratives, Unnatural Narratology: Beyond Mimetic Models". Narrative I8.2 (2010): II3-I36.

Alber, Jan, Stefan Iversen, Henrik Skov Nielsen och Brian Richardson. "What Is Unnatural about Unnatural Narratology? A Response to Monika Fludernik". Narrative 20:3 (20I2): 37I-382. Aronen, Eeva Kaarina. Kallorumpu. Helsingfors: Teos, 20II (=KR).

Clüver, Claus. "Ekphrasis Reconsidered. On Verbal Representations of Non-Verbal Texts". Interart Poetics. Essays on the Interrelations of the Arts and Media. Red. Ulla-Britta Lagerroth, Hans Lund och Erik Hedling. Amsterdam och Atlanta: Rodopi B.V., 1997. 19-34.

Cohn, Dorrit. Transparent Minds: Narrative Modes for Presenting Consciousness in Fiction. Princeton: Princeton UP, 1978.

Cohn, Dorrit. The Distinction of Fiction. Baltimore och London: The Johns Hopkins UP, 1999.

Culler, Jonathan. Structuralist Poetics. Structuralism, Linguistics and the Study of Literature. London: Routledge \& Kegan Paul, 1975.

Culler, Jonathan. "Omniscience". Narrative I2.I (2004): 22-34.

Fludernik, Monika. "History and Metafiction. Experientality, Causality, and Myth". Historiographic Metafiction in Modern American and Canadian Literature. Red. Bernd Engler och Kurt Müller. Paderborn, München, Wien och Zürich: Ferdinand Schöningh, 1994.

Fludernik, Monika. Towards a 'Natural' Narratology. London och New York: Routledge, 1996. Fludernik, Monika."Natural Narratology and Cognitive Parameters". Narrative Theory and the Cognitive Sciences. Red. David Herman. Stanford: CSLI Publications, 2003. 243-267.

Fludernik, Monika. "How Natural is 'Unnatural Narratology'; or, What Is Unnatural about Unnatural Narratology?". Narrative 20.3. (2012): 357-370.

Genette, Gérard. Narrative Discourse. Oxford: Basil Blackwell, 1980/1972.

Genette, Gérard. Fiction \& Diction. Ithaca: Cornell University Press, 1993/I99I.

Genette, Gérard. Paratexts: Tresholds of Interpretation. Cambridge: Cambridge UP, 1997/1987.

Hamburger, Käte. The Logic of Literature. Bloomington och Indianapolis: Indiana UP, 1993/1973.

Heffernan, James A. W. "Ekphrasis and Representation". New Literary History 22.2 (I99I): 297-316.

Herman, David. Story Logic. Problems and Possibilities of Narrative. Lincoln och London: Nebraska UP, 2002.

Herman, David. Basic Elements of Narrative. Oxford: Wiley-Blackwell, 2009. 
Hutcheon, Linda. A Poetics of Postmodernism. History, Theory, Fiction. London och New York: Routledge, I999/1988.

McHale, Brian. Postmodernist Fiction. London och New York: Routledge, 1987.

Mitchell, W. J. T. Picture Theory. Essays on Verbal and Visual Representation. Chicago och London: Chicago UP, I994.

Mäkelä, Maria. ”Navigating - Making Sense - Interpreting (The Reader behind La Jalousie)”. Narrative, Interrupted: The Plotless, the Distrubing and the Trivial in Literature. Red. Markku Lehtimäki, Laura Karttunen och Maria Mäkelä. Berlin och New York: Walter de Gruyter, 2012. I39-I52.

Nelles, William. "Omniscience for Atheists: Or, Jane Austen's Infallible Narrator". Narrative I4.2 (2006): II8-I3I.

Nielsen, Henrik Skov. "The Impersonal Voice in First-Person Narrative Fiction”. Narrative I2.2 (2004): I33-I5O.

Nielsen, Henrik Skov. "Natural Authors, Unnatural Narration”. Postclassical Narratology: Approaches and Analyses. Red. Jan Alber och Monika Fludernik. Columbus: The Ohio State UP, 20IO. 275-3OI.

Phelan, James. Living to Tell about It. A Rhetoric and Ethics of Character Narration. Ithaca och London: Cornell UP, 2005.

Ryan, Marie-Laure. Narrative as Virtual Reality. Immersion and Interactivity in Literature and Electronic Media. Baltimore och London: The Johns Hopkins UP, 200I.

Seppälä, Juha. Suomen historia. Helsingfors, Borgå och Juva: WSOY, I998.

Toker, Leona. Eloquent Reticence: Withholding Information in Fictional Narrative. Lexinton: Kentucky UP, I993.

Yacobi, Tamar. "Fictional Reliability as a Communicative Problem". Poetics Today 2.2 (I98I): II3-I26.

Yacobi, Tamar. ”Interart Narrative. (Un)reliability and Ekphrasis”. Poetics Today 2I.4 (2000): 7II-750. 